\title{
Antifungal Activity of Some Plant Extracts against Different Plant Pathogenic Fungi
}

\author{
Abdurrahman Onaran ${ }^{1 *}$ and Hayriye Didem Sağlam ${ }^{2}$
}

\begin{abstract}
The negative environmental impact of pesticides used for pest and disease control is intensively increasing everyday. For this reason, alternative methods of reducing pesticide are being developed. One of the effective methods is to use plant extracts which incorporating natural antifungal substance. The aim of this study was to determine methanol extracts of different parts (leave, flower, root, fruit and shoots) of Trachystemon orientalis, Smilax excelsa, Rhododendron ponticum, Phytolacca americana and Prunus laurocerasus, which were collected from the Black Sea region of Turkey, against three economically important plant disease, Alternaria solani, Botrytis cinerea and Rhizoctonia solani. These diseases cause significant product losses on tomatoes, strawberry, potatoes and cucumber. Antifungal activity of plants extracts were determined by agar plate methods. Different dose of plant extracts (50, 100, 200 and $400 \mathrm{mg} / \mathrm{ml}$ ) were applied against these plant pathogens and the value of mycelial growth inhibition (MGI) and mycelial growth (MG) were recorded. All plant species were showed that significantly distinguished antifungal activities. The highest MGI value (84\%) was recorded on leaf extract of $P$. americana against B.cinerea. The highest antifungal activities against all pathogens were observed doses of $400 \mathrm{mg} / \mathrm{ml}$ from $P$. laurocerasus, $T$. orientalis, $P$ americana, $R$. ponticum and $S$. excelsa respectively. According to this result, plant extracts of natural antifungal subtract can be used as a biological pesticide as an alternative management methods against plant diseases.
\end{abstract}

Keywords-Antifungal activities, plant extracts, plant diseases, Mycelial growth inhibition.

\section{INTRODUCTION}

$\mathrm{T}$ HE rich content of antifungal substances in plants are being used biopesticide since up to the beginning of human civilization. Antifungal effects of plant and plant products emerge clearly every day. Antifungal substances which are obtained from plants have no side effect against environment thus, giving a significant advantage. Nowadays, a commercial pesticide used against plant diseases is found to cause damage to environment and human health. Because of that conducting a research of alternative control methods comes into prominence for minimizing used commercial pesticide. Research found that compounds in the structure of plants and essential oil were showed antifungal, antibacterial, insecticidal, nematicidal, herbicidal and antiviral activities [18].

\footnotetext{
${ }^{1}$ Gaziosmanpaşa University, Faculty of Agriculture, Department of Plant Protection, 60150, Tokat, Turkey

${ }^{2}$ Ahi Evran University, Faculty of Agriculture, Department of Plant Protection, 40200, Kırşehir, Turkey.
}

Turkish plant fauna is very rich. Some plants are endemic as Trachystemon orientalis (L.) G. Don (Boraginaceae) is found only Black Sea Region in Turkey [9]. T.orientalis is 30$40 \mathrm{~cm}$ length, rhizomatous, latifolius and pilose, blue-violet flowers and herbaceous perennial plants [10-11]. Smilax excelsa L. (Smilacaceae) is up to $15 \mathrm{~m}$ length, spiny, climber woody plant [12]. Rhododendron ponticum (Ericaceae) is also only found Black Sea Region in Turkey, Rhododendron genus has 800 species [13]. Phytolacca americana is a herbaceous perennial plant, It has simple leaves on green to purplish stems. Fruits are dark reddish and blackish colour, and spheroidal shape [14]. Prunus laurocerasus L., (Rosaceae) is an evergreen shrub or medium-sized tree, flowers are creamywhite colour, and leaves are dark green, leathery, shiny, with a finely serrated margin [15].

A. solani, B. cinerea and $R$. solani are important plant diseases that causes significantly yield losses in our country and in the world. A.solani is very common diseases on tomatoes which are known early blight [16]. B. cinerea is caused significant fruit losses on strawberry plants [17]. $R$. solani is known wherever potatoes are grown and reducing yield and quality [18].

The aim of this study was to determine alternative methods for important plant diseases such as Alternaria solani (Ell. ve G. Martin), Botrytis cinerea pers.:Fr, and Rhizoctonia solani Kühn by plant extracts. For this purpose, the methanol extracts of five plants (Trachystemon orientalis, Smilax excelsa, Rhododendron ponticum, Phytolacca americana and Prunus laurocerasus) tested and their antifungal activities were determined.

\section{MATERIAL AND METHODS}

\section{A. Plant Materials}

Plant species were collected from Düzce, Giresun and Trabzon province in Turkey 2014 (Table 1). The plant parts were air-dried at room temperature for three weeks in dark conditions. The dried plant parts were milled to a fine powder in a mill. 
TABLE 1. LIST OF PLANT SPECIES

\begin{tabular}{|c|c|c|c|}
\hline Scientific name & Family & Part used & $\begin{array}{c}\text { Place of } \\
\text { collection }\end{array}$ \\
\hline $\begin{array}{l}\text { Trachystemon } \\
\text { orientalis L. G.Don }\end{array}$ & Boraginaceae & $\begin{array}{l}\text { Leaf, } \\
\text { Flower, } \\
\text { Root }\end{array}$ & Düzce,Turkey \\
\hline Smilax excelsa $L$. & Smilacaceae & Shoots & Düzce, Turkey \\
\hline $\begin{array}{l}\text { Rhododendron } \\
\text { ponticum L. }\end{array}$ & Ericaceae & Leaf & Düzce, Turkey \\
\hline $\begin{array}{l}\text { Phytolacca americana } \\
\text { L. }\end{array}$ & Phytolaccaceae & Leaf, Fruit & Giresun, Turkey \\
\hline $\begin{array}{l}\text { Prunus laurocerasus } \\
\text { L. }\end{array}$ & Rosaceae & Leaf, Fruit & Trabzon,Turkey \\
\hline
\end{tabular}

\section{B. Fungi Cultures}

The plant pathogenic fungi (Table 2) used in the research were obtained from the stock cultures in laboratory of phytoclinic, Department of Plant Protection, Faculty of Agriculture, University of Ahi Evran University, Turkey. Plants pathogens were grown on Petri dishes $(90 \mathrm{~mm})$ containing $20 \mathrm{ml}$ of PDA and incubated at $25 \pm 2^{\circ} \mathrm{C}$ for 7 days, these fungi cultures were used in study.

TABLE 2. LIST OF PLANT PATHOGENS

\begin{tabular}{lll}
\hline Plant pathogens & Origin & $\begin{array}{l}\text { Place of } \\
\text { İsolation }\end{array}$ \\
\hline $\begin{array}{l}\text { Alternaria solani (Ell. And G. } \\
\text { Martin) }\end{array}$ & Tomato & Antalya, Turkey \\
$\begin{array}{l}\text { Botrytis cinerea pers.:Fr } \\
\text { Rhizoctonia solani Kühn. }\end{array}$ & Strawberry & Antalya, Turkay \\
\hline
\end{tabular}

\section{C.Plant Extracts}

Powdered plant materials (each one was $100 \mathrm{~g}$ ) were extracted with methanol by incubated orbital shaker (Lab. Corporation Group, Model-SI-300) at $120 \mathrm{rpm}$ for $72 \mathrm{~h}$ $\left(30^{\circ} \mathrm{C}\right)$. After that it was evaporated to dryness in a rotary evaporator (Heildolph Group, Model-Hei-Vap Presicion). The concentrate was then diluted with $50 \%$ Acetone. Each plant extract was used at 50, 100, 200 and, $400 \mathrm{mg} / \mathrm{ml}$ doses [19].

\section{D.In vitro Antifungal Activity}

The antifungal activities of the plant extracts were determined by agar plate method [20]. Plant extracts were added to PDA at $40{ }^{\circ} \mathrm{C}$ to give the concentration of 50, 100, 200 and $400 \mathrm{mg} / \mathrm{ml}$ for each extract and then the PDA with extracts were poured $\left(\sim 10 \mathrm{ml} / \mathrm{plate}^{-1}\right)$ each alone in petri plates (60 $\mathrm{mm}$ in diameter). Seven-day-old agar discs $(5 \mathrm{~mm}$ in diameter) bearing the desired fungus growth was transferred in the petri plates. These fungus cultures were incubated at $25 \pm 2$ ${ }^{\circ} \mathrm{C}$ for 7 days. Fungus growths were recorded daily [1]. Commercial fungicide [Thiram $80 \%$ (Hektaş, group)] was used as a positive control and $50 \%$ acetone was used as a negative control. Experiment set up 4 replications and repeated twice.

The percentage of mycelial growth inhibition was calculated accordingly the formula mentioned by [21].

I; Mycelial growth inhibition

$$
\mathrm{I}=100 \times(\mathrm{dc}-\mathrm{dt}) / \mathrm{dc}
$$

dc; Is the mycelial growth in control

$\mathrm{dt}$; Is the mycelial growth in treatment

\section{E. Statistical Analysis}

The data were analyses using Analysis of Variance (ANOVA) test. Differences between means were determined by the TUKEY test (at the 0.05 probability level). The software SPSS 13.0 was used to conduct all the statistical analysis.

\section{RESULTS AND DISCUSSION}

In this study, the methanol extracts of $T$. orientalis [leaves (TL), flower (TF) and root (TR)], S. excelsa [shoot (SS)], $R$. ponticum [leaves (RL)], P. americana [leaves (PAL) and flower (PAF)] and $P$. laurocerasus [leaves (PLL) and fruit (PLF)] were tested. Experiment of plant extracts were conducted by agar plate cultures and identifying antifungal activities.

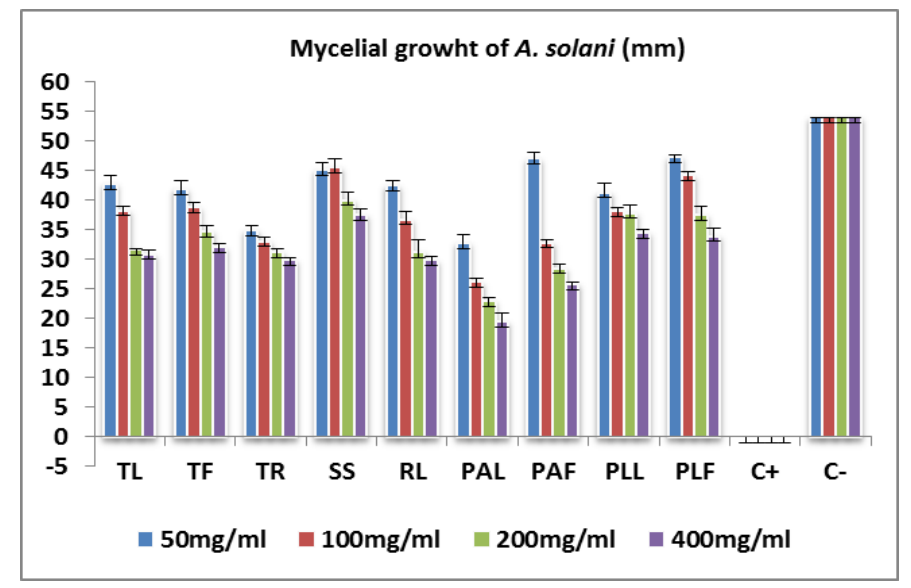

Figure 1. Mycelial growth of Alternaria solani aganist plant extracts

The methanol extracts of all plant parts displayed varied antifungal activity on A.solani, B.cinerea and R.solani. The developments of mycelium of all pathogens have been suppressed by compare with negative control. All plant extract were showed antifungal effect depending on dose increasing. The developments of mycelium in controls were found on A.solani and B.cinerea at $60 \mathrm{~mm}$, and R.solani at $51 \mathrm{~mm}$ (Fig. $1,2$ and 3$)$.

All the results of antifungal activities considered together; extracts of PAL, PLL and RL against $B$. cinerea were showed highly effective antifungal activities. In other extracts discernible effect was determined (Fig 2). The highest effect against A.solani was observed by extracts of PAL,TR, PAF and TL respectively. The extracts of RL, PAF and SS were displayed the highest effect against $R$. solani. 


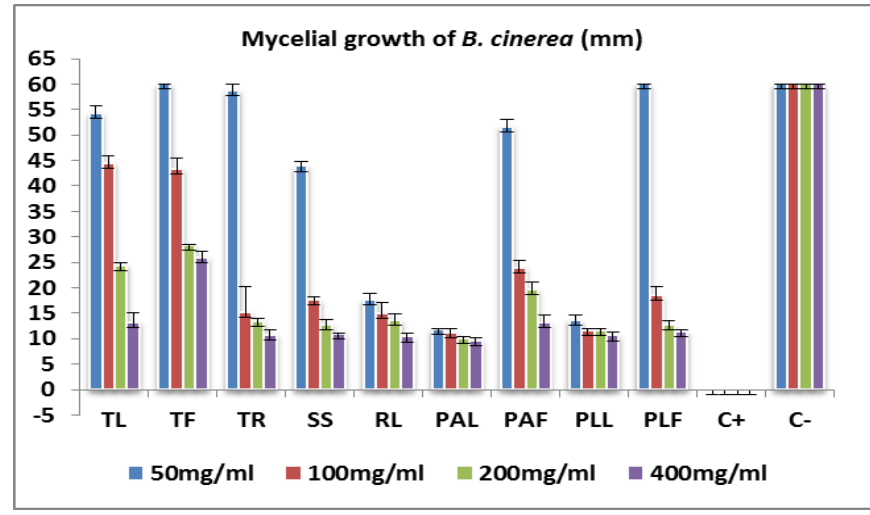

Figure 2. Mycelial growth of Botrytis cinerea aganist plant extracts

$B$. cinera has been observed the most sensitive diseases against plant extracts. This was followed by $A$. solani and $R$. solani. PLL has shown the highest antifungal effect from all doses against all pathogens. This was followed by the extracts of TF, PAF, TS, RF, PAF, TL, PLF and SS respectively (Fig. 1-3).

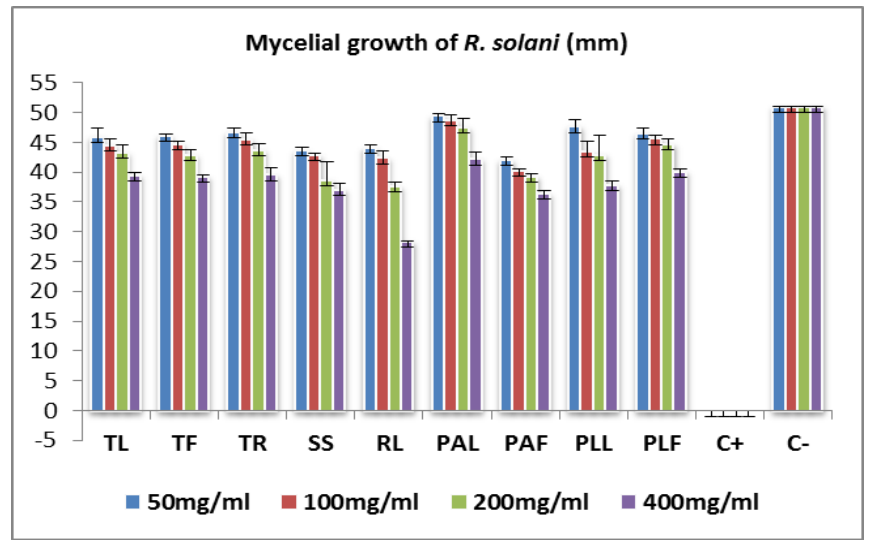

Figure 3. Mycelial growth of Rhizoctonia solani aganist plant extracts

According to the result of mycelium that percent of inhibition rates were found. These rates were displayed different level to compare the type of plants and parts used. Nine methanol extracts against each pathogen were found different level of inhibition mycelium rates (Table 1). Positive control showed that $100 \%$ mycelium grown inhibition. As the dose increases, the percent has been shown an increase in inhibition rates.

\begin{tabular}{|c|c|c|c|c|c|c|c|c|c|c|c|c|}
\hline \multirow{2}{*}{$\begin{array}{l}\text { Plant } \\
\text { Pathogens }\end{array}$} & \multirow{2}{*}{$\begin{array}{c}\text { Doses } \\
(\mathrm{mg} / \mathrm{ml})\end{array}$} & \multicolumn{9}{|c|}{ Plant extracts (\%) } & \multicolumn{2}{|c|}{ Controls } \\
\hline & & TL & $\mathrm{TF}$ & TR & SS & $\mathrm{RL}$ & PAL & PAF & PLL & PLF & $\begin{array}{l}\mathrm{C} \\
- \\
\end{array}$ & $\begin{array}{l}\mathrm{C} \\
+\end{array}$ \\
\hline \multirow[t]{4}{*}{ A solani } & 50 & 21 & 22 & 35 & 15 & 21 & 39 & 13 & 23 & 12 & - & 100 \\
\hline & 100 & 29 & 28 & 39 & 16 & 32 & 52 & 39 & 29 & 18 & - & 100 \\
\hline & 200 & 41 & 36 & 42 & 26 & 42 & 57 & 47 & 30 & 31 & - & 100 \\
\hline & 400 & 43 & 41 & 45 & 30 & 45 & 64 & 52 & 36 & 37 & - & 100 \\
\hline \multirow[t]{4}{*}{ B. cinerea } & 50 & 9 & - & 2 & 27 & 71 & 71 & 14 & 77 & - & - & 100 \\
\hline & 100 & 26 & 28 & 75 & 71 & 75 & 75 & 60 & 81 & 69 & - & 100 \\
\hline & 200 & 59 & 53 & 78 & 79 & 77 & 77 & 67 & 81 & 79 & - & 100 \\
\hline & 400 & 78 & 57 & 82 & 82 & 83 & 84 & 77 & 82 & 81 & - & 100 \\
\hline \multirow[t]{4}{*}{ R. solani } & 50 & 10 & 10 & 8 & 14 & 14 & 3 & 18 & 7 & 9 & - & 100 \\
\hline & 100 & 13 & 12 & 11 & 16 & 18 & 4 & 21 & 15 & 11 & - & 100 \\
\hline & 200 & 15 & 16 & 14 & 24 & 26 & 7 & 23 & 16 & 12 & - & 100 \\
\hline & 400 & 23 & 24 & 23 & 27 & 44 & 17 & 29 & 26 & 21 & - & 100 \\
\hline
\end{tabular}

For Figure 1-3 and Table 3. (-)= No antifungal activity; TL=Leaf extract of $T$. orientalis; $\mathrm{TF}=$ Flower extract of $T$. orientalis; $\mathrm{TR}=\mathrm{Root}$ extract of $T$. orientalis; SS=Shoot extracts of Smilax excelsa; $\mathrm{RF}=$ Leaf extract of Rhododendron ponticum; PAL; Leaf extract of Phytolacca americana; PAF=Fruit extracts of Phytolacca americana; PLL= Leaf extract of Liquidambar orientalis; PLF $=$ Fruit extract of Prunus laurocerasus. C-=Negative control (50\% Asetone); $\mathrm{C}+=$ Positive control (80\% Thiram).
Many articles were published about antifungal properties of target plant pathogenic fungi. Water extracts from leaves, root and flowers of Trachystemon orientalis has been reported having antifungal effect on Ascochyta rabiei, Fusarium oxysporum f. sp. melonis, Fusarium oxysporum f. sp. radicislycopersici, Verticillium dahliae and Rhizoctonia solani. The highest mycelium growth inhibitor showed flower water extracts. This was followed by leaves and root water extracts respectively. All doses of flower water extracts which used for A. rabiei, $V$. dahliae and $R$. solani, was completely stopped mycelium growth [1]. Another study was about Rhododendron ponticum, Rhododendron luteum, Rhododendron smirnovii and Rhododendron caucasicum displayed antifungal and antibacterial effects on pathogens. Leaves and flower extracts of $R$. ponticum were reported that highly antifungal and antibacterial properties. The highest antifungal effect against tested organisms was showed $R$. ponticum [22]. The methanol extracts of four plant species were tested against seven plant pathogens (Magnaporthe oryzae, Rhizoctonia solani, Puccinia recondita, Blumeria graminis $f$. sp. hordei, Botrytis cinerea, 
Phytophthora infestans, Colletotrichum capsici) and displayed antifungal activities. In this study, the methanol extracts of Phytolacca americana showed different level of antifungal effect of the plant species used, against Magnaporthe oryzae, Botrytis cinerea, Phytophthora infestans under in vitro and in vivo conditions. In addition, methanol extract of $P$. americana at $3.000 \mathrm{ppm}$ dose was showed antifungal effect on Magnaporthe oryzae (62,5\%) , Rhizoctonia solani (26.7\%), Puccinia recondita (26.7\%), Blumeria graminis $f$. sp. hordei (0.0\%), Botrytis cinerea (85\%), Phytophthora infestans (82.1\%) and Colletotrichum capsici (20\%) [23]. In another study, methanol extracts from leaves and fruits of Cornus mas, Morus nigra, and Prunus laurocerasus were tested against Gnomonia leptostyla and has identified that showed antifungal activities. Mycelium inhibition was obtained $55.14 \%$ and $49.06 \%$ at $750 \mathrm{mg}$ dose from leaves extract and fruit extracts of Prunus laurocerasus respectively [24].

As a result, the plant extracts which used in our study was showed a different level of antifungal activities in a dose depend manner. The extracts determined activities showed that can be used as biopesticides. In addition, first time displayed antimicrobial properties of Smilax excelsa by this study.

\section{ACKNOWLEDGMENT}

This study was supported by University of Ahi Evran with the Project Number PYO. ZRT.4001.14.001.

\section{REFERENCES}

[1] A. Onaran, and M. Yılar, "Antifungal activity of Trachystemon orientalis L. aqueous extracts against plant pathogens," J. Food Agric. Environ., vol. 10, pp. 287-291, July-October 2012.

[2] A. Gökçe, M.E. Whalon, H. Çam, Y. Yanar, İ. Demiștaş, and N. Gören, "Plant extract contact toxicities to various developmental stages of Colorado potato beetles (Coleoptera: Chrysomelidae)," Annals of Applied Biology, vol. 149, pp.197-202, October 2006 http://dx.doi.org/10.1111/j.1744-7348.2006.00081.x

[3] B. Dülger, and N. Hacioğlu, "Antifungal activity of endemic Salvia tigrina in Turkey," Tropical Journal of Pharmaceutical Research, vol. 7, pp. 1051-1054. September 2008. http://dx.doi.org/10.4314/tjpr.v7i3.14690

[4] Ş. Kordali, A. Çakır, T.A. Akcin, E. Mete, A. Akcin, T. Aydın, and H. Kılıç, "Antifungal and herbicidal properties of essential oils and nhexane extracts of Achillea gypsicola Hub-Mor. and Achillea biebersteinii Afan. (Asteraceae)," Industrial Crops and Products, vol. 29, pp. 562-570. March 2009. http://dx.doi.org/10.1016/j.indcrop.2008.11.002

[5] I. Kepenekçi, and H.D. Sağlam, "Extracts of Some Indigenous Plants Affecting Hatching and Mortality in the Root-Knot Nematode [Meloidogyne javanica (Treub) Chitwood]," Egyptıan Journal of Biological Pest Control. Vol. 25, pp. 39-44. January 2015.

[6] E. Hosein, S. Azar, K. Parivash, B. Alireza, B. Mansour, and S. Leila, "Antifungal Effect of Zataria multiflora: An In vitro Evaluation.," Global Veterinaria, vol. 4, pp. 140-143. March 2010.

[7] S.J. Chang, Y.C. Chang, K.Z. Lu, Y.Y. Tsou, and C.W. Lin, "Antiviral activity of Isatis indigotica extract and its derived indirubin against Japanese encephalitis virus,” Evid Based Complement Alternat Med, doi: 10.1155/2012/925830, July 2012. http://dx.doi.org/10.1155/2012/925830

[8] S. Kordali, A. Usanmaz, A. Cakir, A. Cavusoglu, and S. Ercisli, "In Vitro antifungal effect of essential oils from Nepeta meyeri Benth," Egyptıan Journal of Biological Pest Control, vol. 23, pp. 209-213, July 2013.

[9] Ö.E. Akçin, N. Kandemir, and Y. Akçin, "A morphological and anatomical study on a medicinal and edible plant Trachystemon orientalis (L.) G.Don (Boraginaceae) in the Black Sea Region,” Turkish Journal of Botany, vol. 28, pp. 435-442, July 2004.

[10] J.R. Edmondson, Trachystemon D.Don. In: Davis PH (ed.). Flora of Turkey and the East Aegean Islands, 6 st. ed. Edinburgh, Edinburgh University Press. 1978, pp. 386-387.

[11] T. Baytop, Türkçe bitki adları sözlüğü, Atatürk kültür dil ve tarih yüksek kurumu, Türk dil kurumu yayınları: 578, Ankara, 1994.

[12] Anonimous, (May 2015a). Melocan (Saparna) (Smilax excelsa). Avaliable: http://tr.wikipedia.org /wiki /Melocan

[13] Anonimous, (May 2015b). Ormangülü, (Rhododendron ponticum). Avaliable: http://tr.wikipedia.org/wiki/Ormang\% C3\%BCl\%C3\%BC

[14] P.H. Davis, Flora of Turkey and East Aegean Islands, 2 st. ed., Edinburg, 1967.

[15] Anonimous. (May 2015c). Karayemiş (Prunus laurocerasus). Avaliable: http://tr.wikipedia. org/wiki/Karayemi\%C5\%9F

[16] S. Yazici, Y. Yanar, and I. Karaman, "Evaluation of bacteria for biological control of early blight disease of tomato,” Afr. J. Biotechnol, vol. 10,pp. 1573-1577. February 2011.

[17] B. Williamson, B. Tudzynski, P. Tudzynski, and J. A. L. Kan, "Botrytis cinerea: the cause of grey mould disease," Molecular Plant Pathology, vol. 8, pp. 561-580, September 2007. http://dx.doi.org/10.1111/j.1364-3703.2007.00417.x

[18] Y. Yanar, G. Yllmaz, I. Cesmeli, and S. Coskun, "Characterization of Rhizoctonia solani isolates from potatoes in turkey and screening potato cultivars for resistance to AG 3,” Phytoparasitica vol. 33, pp. 370-376. July 2005. http://dx.doi.org/10.1007/BF02981304

[19] İ. Kadıoğlu, Y. Yanar, and U. Asav, "Allelopathic effects of plant extracts against seed germination of some weeds," Journal of Environmental Biology, vol. 3 pp. 472-475. April 2005.

[20] M.O. Nwosu, and J.l. Okafor, "Preliminary studies of the antifungal activites of some medicinal plants against Basidiobolus and some other pathogenic fungi.," Mycoses, vol. 38, pp. 191-195, May-June 1995. http://dx.doi.org/10.1111/j.1439-0507.1995.tb00048.x

[21] D.K. Pandey, N.N. Tripathi, R.D. Tripathi, and S.N. Dixit, "Fungitoxic and phytotoxic properties of essential oil of Hyptis suaveolens," Z. Pflanzenk, vol. 89 pp. 344-349. 1982.

[22] Ö. Ertürk, F.Pehlivan Karakaş, D. Pehlivan, and N. Nas, "The Antibacterial and Antifungal Effects of Rhodedendron Derived Mad Honey and Extracts of Four Rhododendron Species.," Turk J Biol, vol. 33, pp. 151-158, 2009.

[23] V.K. Bajpai, K.H. Baek, E.S. Kim, J.E. Han, M. Kwak, K. Oh, J.C. Kim, S. Kim, and G.J. Choi, "In Vivo Antifungal Activities of the Methanol Extracts of Invasive Plant Species Against Plant Pathogenic Fungi," Plant Pathology Journal, vol. 28 pp. 317-321, September 2012. http://dx.doi.org/10.5423/PPJ .NT.04.2012.0056

[24] Ö. Kalkışım, "In vitro antifungal evaluation of various plant extracts against walnut anthracnose (Gnomonia leptostyla (Fr.) Ces et de Not.)," J. Food Agric. Environ, Vol. 10, pp. 309-313, July-October 2012. 